\title{
Cardiological screening in young oncological convalescents before sport participation by heart rate variability analysis
}

\section{Vyhledávání kardiomyopatie u mladých onkologických rekonvalescentů před sportovní aktivitou analýzou variability srdeční frkvence}

\author{
${ }^{1}$ Jan Novotný, ${ }^{2}$ Hana Hrstková, ${ }^{2}$ Lubomír Elbl, ${ }^{1}$ Martina Bernaciková \\ ${ }^{1}$ Faculty of Sports Studies of Masaryk University Brno, Czech Republic \\ Medical Faculty of Masaryk University Brno, Czech Republic
}

\begin{abstract}
Young convalescents after oncological treatment are at risk of toxic cardiomyopathy development. An evaluation of their capability to an exercise or sport needs examination of heart state.

Goal of work: To evaluate the heart rate variability (HRV) analysis as a screening method in early diagnostics of toxic cardiomyopathy by patients after oncological chemotherapy in childhood.

The study was designed as an individual correlation test of HRV parameters to echocardiographical values. Probands: 85 girls and boys after oncological treatment by doxorubicin and/or cyclophosphamid; aging 7-29 years. Heart rate (beat to beat) was monitored during 5 minutes of vertical position, and in upright position. The echocardiographical measurement was performed in a rest and after dynamic exercise.

The values of the HRV parameters have no normal distribution. We found close relations of the rest ejection fraction to $3 \mathrm{HRV}$ parameters - to spectral power of HF band in lying position, and to MSSD in lying and in stand-up position. Both of last HRV parameters represent above all a vagal activity. We found a close relation of after-stress ejection fraction to only one HRV parameter - to VLF/LF spectral power rate in lying position. Close relations were found in difference of the rest - after-stress EF (d-EF) to seven HRV parameters in lying position.

Therefore we believe that $H R V$ analysis, as an instrumental, timing and personal less demanding method, can be used for cardiomyopathy screening in oncological paediatric patients before exercise and sport practise.
\end{abstract}

\section{ABSTRAKT}

U mladých lidí po onkologické léčbè je riziko rozvoje kardiomyopatie. Posuzování jejich schopnosti kpohybové aktivitě vyžaduje také vyšetření stavu srdce.

Cílem práce bylo posoudit analýzu variability srdeční frekvence (HRV) jako vyhledávací metodu toxické kardiomyopatie u pacientů po chemoterapii $v$ dètství.

Ve studii je zjištována korelace mezi parametry HRV a echokardiografickými hodnotami. Probandi: 85 dèvčat a chlapců po onkologické léčbě doxorubicinem a cyklofosfamidem, ve věku 7-29 let. Srdeční frekvence tep po tepu byla sledována během 5minutové polohy vleže a vstoje. Echokardiografické měření bylo provedeno $v$ klidu a po dynamické zátěži.

Hodnoty HRV nemají normální rozložení. Nalezli jsme těsný vztah mezi klidovou ejekční frakcí a třemi parametry variability, spektrální výkon pásma HF vleže, MSSD vleže a vstoje. Oba poslední parametry reprezentují vagovou aktivitu. Zjistili jsme vztah pozátěžové ejekční frakce k poměru spektrálních výkonů $V L F / L F$ vleže, a také mezi rozdílem klidové a pozátěžové ejekční frakce a sedmi parametry HRV vleže.

Domníváme se, že analýza HRV, technicky, časově a personálně méně náročná metoda, by mohla být používána ve vyhledávání kardiomyopatie u onkologických pacientů pred započetím jejich sportovní aktivity.

Keywords: $\quad$ heart rate variability, cardiomyopathy, oncological therapy, exercise, sport.

Klíčová slova: variabilita srdeční frekvence, kardiomyopatie, onkologická terapie, cvičení, sport. 
Acknowledgements: The research was supported by Internal Grant Agency of Ministry of Public Health of the Czech Republic No. 5920-3.

\section{INTRODUCTION}

Lately a number of young convalaescents after successful oncological treatment, and that wants comeback to the full life activity, grow. An evaluation of their capability to an exercise or sport needs periodical examination of heart state because the children after oncological treatment are at risk of toxic cardiomyopathy. Anthracyclins, above all doxorubicin and daunorubicin, are components of the therapeutic protocols of paediatric malignity. Nevertheless cardio toxicity is a risk of the treatment. The toxic cardiopathy can arise immediately or more years after anthracyclin application (Schneider et al. 2003). Moderate endurance training is for the patients important because the exercise can prevent doxorubicininduced mitochondropathy and reduce the development of cardiac apoptosis (Ascensão et al. 2008).

A proper diagnostic method of the cardiopathy is echocardiography (Bossi et al. 2001, Elbl et al. 2001, Hauser et al. 2001). The question of a diagnostic use of heart rate variability (HRV) analysis in cardiomyopathy, as a toxic side effect of oncological therapy in childhood, has not been solved yet sufficiently. An additional reason of our searching was a requirement of early diagnostics of the cardiomyopathy, in its sub-clinic stage. Physiological studies have already brought for many years a piece of knowledge about heart rate variability (HRV) (Ganong 1999, Honzíková 1990). It seems that the principal role of this regulation is in the neural autonomic centres. Its activities depend on a lot of physical and chemical, endogenous and exogenous factors (Task Force 1996). Pathological functional disorders of a cardiovascular, neural, endocrinological, respiratory and other system imprint to HRV changes (Havorka et al. 2008). Then the HRV analysis has diagnostic value in the medical fields, above all in cardiology, neonatology, diabetology and neurology (Havorka et al. 2008, van Ravenswaaij-Arts et al. 1993, Štejfa et al. 1998). It has no ability to separate a kind of cell damage, but it can contribute to evaluation of damage level. The cardiologic application of HRV analysis help to solve the problems of transplanted heart rejection, death risk level determination by patients after heart attack, evaluation of myocardial damage in cardiopathy and others (Bonaduce et al. 1997, Doven et al. 2001). A 24-hours HRV was analysed for prediction of ventricular arrhytmias in idiopathic dilated cardiomyopathy (Grimm et al. 2003, Grimm et al. 2005, Hofmann et al. 1996, Palacios et al. 2007). Mörner et al. (2005) assessed parasympathetic dysfunction in hypertrophic cardiopathy by HRV analysis of short-time and 24-h ECG records. The untreated patients were lower HRV than treated with beta-blockade.

The HRV analysis as diagnostic method is non-specific, but very sensitive (Babcock et al. 1996).

Aim of the study:

To evaluate the HRV analysis as a screening method of early toxic cardiomyopathy diagnostics by young oncological patients before their exercise and sport participation.

\section{PATIENTS AND METHODS}

The study was designed as a correlation test of HRV parameters to echocardiographical values that is reference diagnostic method.

The study group:

We have tested eighty five patients (39 girls and 46 boys) after oncological treatment of acute leukaemia, Hodgkin's disease, and others by doxorubicin and or cyclophosphamid.

Aging of the patients was $7-29$ years $(=17,4 ; s=5,1)$. The period between the examination and the treatment was $1-26$ years $(=8,9 ; s=5,4)$.

In examination time the probands had not get health complications (infection, cardiovascular, classic heart arrhythmia (ectopic beats, blocks). There were no clinical symptoms of cardiomyopathy founded by these children.

The heart rate variability measurement and analysis:

Heart rate (HR) like R-R intervals were measured by method beat to beat in short-term electrocardiographical (ECG) record during a rest (after previous lull in lying position when HR was no longer de- 
creasing, minimally 5 minutes) 5 minutes in lying position, and than 5 minutes in standing position. The examines were pursued between 8,00 and 12,00 a.m. in ambulatory care centre of paediatric clinic in the standard conditions (temperature $22-26^{\circ} \mathrm{C}$, humidity $40-80 \%$ ). It was used the VariaCardio TF4 system (SIMA Media Olomouc) with sampling frequency $1000 \mathrm{~Hz}$. The sensor is in thoracic elastic band with two electrodes (load system CC5) and radio-transmitter. The ECG potential was transported to a receiver connecting to computer. The system is supported by the software for the monitoring and for the time and spectral (the fast Fourier transformation) analysis of R-R intervals (van Ravenswaaij-Arts et al. 1993). The system shows the supervisory ECG curve during measurement.

There was measured and or calculated $19 \mathrm{HRV}$ parameters for lying position, 10 for standing position, and 7 for a relation lying/standing (Tab.1). Their values were compared with 3 selected echocardiographical parameters (Tab.1). The relative parameters (\% of reference values) were related to HRV analysis by a healthy population (Novotný et al. 1998). Spectral parameters were calculated for three frequency bands: very low frequency $0-0,05 \mathrm{~Hz}$ (VLF), low frequency $0,05-0,15 \mathrm{~Hz}(\mathrm{LF})$, high frequency $0,15-0,5 \mathrm{~Hz}(\mathrm{HF})$.

The dynamic echocardiographical measurement:

A bicycle ergometer Ergoline 400 was used for the dynamic exercise $(25 \mathrm{~W}+25 \mathrm{~W}$ per $2 \mathrm{~min}$ to exhaustion). The echocardiographical measurement (4 standard profile of left ventricle) was done before and immediately after the stress, both in a lying position. For the ejection fraction assessment we used classical indicators from M-mode (Babcock et al. 1996).

Statistical data processing:

For a correlation testing between HRV and echocardiographical values we have used the Spearman rank correlation test, and the multiple linear regression tests.

Table1: List of heart rate variability and echocardiographical parameters

\begin{tabular}{|l|l|}
\hline \multicolumn{2}{|c|}{ Heart rate variability parameters } \\
\hline l-TP & Total spectral power in lying position $\left(\mathrm{ms}^{2}\right)$ \\
\hline l-VLF & Spectral power of very low frequency in lying position $\left(\mathrm{ms}^{2}\right)$ \\
\hline l-1LF & Spectral power of low frequency in lying position $\left(\mathrm{ms}^{2}\right)$ \\
\hline l-1HF & Spectral power of high frequency in lying position $\left(\mathrm{ms}^{2}\right)$ \\
\hline l-VLFnu & Spectral power of very low frequency in lying position (n.u.) \\
\hline l-LFnu & Spectral power of low frequency in lying position (n.u.) \\
\hline l-HFnu & Spectral power of high frequency in lying position (n.u.) \\
\hline l-TP\% & Total spectral power in lying position (\% of reference) \\
\hline l-VLF\% & Spectral power of very low frequency in lying position (\% of reference) \\
\hline l-LF\% & Spectral power of low frequency in lying position (\% of reference) \\
\hline l-HF\% & Spectral power of high frequency in lying position (\% of reference) \\
\hline l-VLF/LF & Spectral power rate of VLF and LF in lying position \\
\hline l-VLF/HF & Spectral power rate of VLF and HF in lying position \\
\hline l-LF/HF & Spectral power rate of LF and HF in lying position \\
\hline l-VLF/LF\% & Spectral power rate of VLF and LF in lying position (\% of reference) \\
\hline l-VLF/HF\% & Spectral power rate of VLF and HF in lying position $(\%$ of reference) \\
\hline l-LF/HF\% & Spectral power rate of LF and HF in lying position (\% of reference) \\
\hline l-MSSD & $\begin{array}{l}\text { Square root of mean of sum of squares of differences between } \\
\left.\text { adjacent R-R intervals in lying position (ms }{ }^{2}\right)\end{array}$ \\
\hline l-MSSD\% & $\begin{array}{l}\text { Square root of mean of sum of squares of differences between } \\
\text { adjacent R-R intervals in lying position (\% of reference) }\end{array}$ \\
\hline s-TP & Total spectral power in stand-up position (ms $\left.{ }^{2}\right)$ \\
\hline s-VLF & Spectral power of very low frequency in stand-up position (ms $\left.{ }^{2}\right)$ \\
\hline s-LF & Spectral power of low frequency in stand-up position (ms $\left.{ }^{2}\right)$ \\
\hline
\end{tabular}




\begin{tabular}{|l|l|}
\hline \multicolumn{2}{|c|}{ Heart rate variability parameters } \\
\hline s-HF & Spectral power of high frequency in stand-up position $\left(\mathrm{ms}^{2}\right)$ \\
\hline s-LF\% & Spectral power of low frequency in stand-up position (\% of reference) \\
\hline s-HF\% & Spectral power of high frequency in stand-up position (\% of reference) \\
\hline s-VLF/LF & Spectral power rate of VLF and LF in stand-up position \\
\hline s-VLF/HF & Spectral power rate of VLF and HF in stand-up position \\
\hline s-LF/HF & Spectral power rate of LF and HF in stand-up position \\
\hline s-MSSD & $\begin{array}{l}\text { Square root of mean of sum of squares of differences between } \\
\text { adjacent R-R intervals in stand-up position }\left(\mathrm{ms}^{2}\right)\end{array}$ \\
\hline s/l-VLF & Lying/stand-up rate of spectral power of very low frequency $\left(\mathrm{ms}^{2}\right)$ \\
\hline s/l-LF & Lying/stand-up rate of spectral power of low frequency $\left(\mathrm{ms}^{2}\right)$ \\
\hline s/l-HF & Lying/stand-up rate of spectral power of high frequency $\left(\mathrm{ms}^{2}\right)$ \\
\hline s/l-VLF/LF & Lying/stand-up rate of spectral power rate VLF/LF \\
\hline s/l-VLF/HF & Lying/stand-up rate of spectral power rate VLF/HF \\
\hline s/l-LF/HF & Lying/stand-up rate of spectral power rate LF/HF \\
\hline s/l-MSSD & Lying/stand-up rate of MSSD \\
\hline Echocardiographic parameters \\
\hline R-EF & Rest left ventricle ejection fraction in lying position (\%) \\
\hline S-EF & After-stress left ventricle ejection fraction in lying position (\%) \\
\hline d-EF & [Rest] - [after-stress] difference of ejection fraction (\% of k-EF) \\
\hline
\end{tabular}

\section{RESULTS}

We bring the results of the Spearman rank tests of correlation of HRV to echocardiographical parameters. We assume that results are the most relevant. At the next tables (Table 2) we choose only statistical significant cases.

Table 2: The selected statistically significant cases of the Spearman rank correlation test between the HRV and echocardiographical parameters.

\begin{tabular}{|c|c|c|}
\hline & $\mathrm{R}$ & $\mathrm{p}$-level \\
\hline R-EF \& l-HF\% & $-0,223879$ & 0,040638 \\
\hline R-EF \& l-MSSD\% & $-0,291781$ & 0,007081 \\
\hline S-EF \& l-VLF/LF & $-0,247435$ & 0,022425 \\
\hline d-EF \& l-HF & 0,226608 & 0,037024 \\
\hline d-EF \& l-HF\% & 0,258456 & 0,017607 \\
\hline d-EF \& l-VLF/HF & $-0,317197$ & 0,003097 \\
\hline d-EF \& l-VLF/HF\% & $-0,308171$ & 0,004114 \\
\hline d-EF \& l-VLF/LF & $-0,213912$ & 0,049323 \\
\hline d-EF \& l-RR & 0,222628 & 0,040568 \\
\hline d-EF \& l-MSSD & 0,261477 & 0,015640 \\
\hline d-EF \& l-MSSD\% & 0,323970 & 0,002645 \\
\hline R-EF \& s-RR & $-0,231355$ & 0,033138 \\
\hline R-EF \& s-MSSD & $-0,342805$ & 0,001320 \\
\hline d-EF \& s-RR & 0,305956 & 0,004405 \\
\hline
\end{tabular}

Legend: The HRV and sonographic symbols are explained in Table 1.

$\mathrm{R}$ - Spearman rank correlation coefficient, $\mathrm{p}$ - level of statistical probability.

However we did not find out a significance of the Spearman test of a correlation between stand up HRV spectral analysis parameters and S-EF, and stand up/lying HRV rate and S-EF and or d-EF. 
We present statistically significant results of the multiple linear regression tested at the Table 3.

Table 3: The selected statistically significant results of the multiple linear regression of the relationship between the HRV and echocardiographical parameters.

\begin{tabular}{|c|c|c|c|}
\hline & B & SE & p-level \\
\hline R-EF \& l-HF\% & $-0,26676$ & 0,106378 & 0,014178 \\
\hline R-EF \& s/l-VLF & 0,460659 & 0,036206 & 0,000000 \\
\hline R-EF \& s/l-LF & 0,086027 & 0,017655 & 0,000005 \\
\hline R-EF \& s/l-MSSD & 0,692799 & 0,144174 & 0,000007 \\
\hline R-EF \& l-HF\% & $-0,21257$ & 0,102794 & 0,042006 \\
\hline R-EF \& s-HF & $-0,00178$ & 0,000545 & 0,001593 \\
\hline S-EF \& s-HF & $-0,00160$ & 0,000784 & 0,044276 \\
\hline S-EF \& s/l-MSSD & $-2,03238$ & 0,731282 & 0,006789 \\
\hline S-EF \& l-MSSD\% & 0,44121 & 0,197197 & 0,028113 \\
\hline S-EF \& s-LF & 0,00213 & 0,000890 & 0,019004 \\
\hline l-HF\% \& z-EF & $-2,15944$ & 0,96691 & 0,028320 \\
\hline l-HF\% \&d-EF & 1,42054 & 0,60686 & 0,021732 \\
\hline l-MSSD\% \& R-EF & 5,8123 & 1,22196 & 0,000009 \\
\hline l-MSSD\% \& S-EF & $-5,2640$ & 1,02057 & 0,000002 \\
\hline l-MSSD\% \& d-EF & 3,5100 & 0,64053 & 0,000000 \\
\hline s/l-VLF/HF \& R-EF & 18,669 & 8,8430 & 0,037840 \\
\hline s/l-VLF/HF \& S-EF & $-15,833$ & 7,3886 & 0,035123 \\
\hline s/l-VLF/HF \& d-EF & 9,605 & 4,6331 & 0,041335 \\
\hline
\end{tabular}

Legend: The HRV and sonographic symbols are explained at Table 1. Independent variables are in the left side of the first column; dependent variables are in the right side of the first column; B - regression coefficient; SE - standard error, $\mathrm{p}$ - level of statistical probability.

\section{DISCUSSION}

During the Spearman rank correlation analysis we found the close relations of the rest ejection fraction to three HRV parameters - to spectral power of HF band in lying position, and to MSSD in lying and in stand-up position. Both of last HRV parameters represent above all a vagal activity.

We recognized the close relation of after-stress ejection fraction to only one HRV parameter - to VLF/ LF spectral power rate in lying position.

The close relations were found in difference of the rest and after-stress EF to seven HRV parameters in lying position - four parameters of short-time variability (spectral power of HF band, and MSSD in absolute alike in relative values), and two parameters of spectral power rate - VLF/HF and VLF/LF.

A majority of significant correlations are in lying position - ten cases; only one significant case is in stand-up position. The stand-up/lying rate of HRV parameters do not show a statistical significant relation to the echocardiographic parameters.

In accessible literature we did not find comparable studies with the same aging profile of probands, with the same method of HRV analysis. Partially and indirectly we can compare our results with experiences of Walichiewicz's team (1998). They found a close relation between echocardiographic parameters and HRV values of long-time ECG record (24 hours) by adults with dilated cardiomyopathy. Grimm et al. (1998) found a similar negative relationship of LVEF to HRV indicator of parasympathetic activity by patient idiopathic dilated cardiomyopathy, but their HRV analysis was from 24-h ECG recording. Folino et al. (2002) described a significant correlation of 24-h HRV indicator (SDNN) to right as well as to left ventricular ejection fraction by patients with arrhytmogenic right ventricular cardiomyopathy. 
After the regress and correlation analysis we suppose that the low reliability values probably result from large inter-individual variance. These results indicate, that the correlations are not only linear, but frequently exponential or polynomial $\left(2^{\text {nd }}\right.$ level). Among the most interesting 15 trends the short-time HRV parameters (HF, MSSD) are dominant, in lying alike stand-up position.

Due to the results of the multiple linear regression tests we conjecture that the most frequent HRV indicators with close relation to ultrasonographic parameters are absolute and relative values of short-time variability (HF band). The parameters of the time domain analysis of R-R intervals (MSSD) have got a similar relation. One is resulted form a similar physiological consequences (subordination to vagal centre). Both of them present the interesting relation to ejection fraction, in lying alike stand-up position.

This facts lead to supposition, that HRV analysis HRV can be more sensitive indicator of a heart function worsening than echocardiographic parameters. We must not overrate this assumption, because HRV, due to complicated regulatory mechanism, is maybe more connected to neural (Jimenez et al. 1998, Shiigi et al. 1998), respiratory, endocrine and metabolic functions than echocardiographic parameters that are maybe determined mainly by heart state.

\section{Conclusions}

With 85 young oncological convalaescents before exercise and sport participation we found next pieces:

The values of the HRV parameters have no normal distribution.

The basic rest and stress functional echocardiographical parameter (ejection fraction) significant correlate to heart rate variability parameters from short-time record (5 minutes).

The dominant relations are between the rest - after loading difference of the EF to short-time HRV parameters (HF-band spectral power, MSSD) in lying and stand-up position.

Therefore we believe that HRV analysis, as an instrumental, timing and personal less demanding method, can be used for cardiomyopathy screening in subclinical stage by persons after oncological cardiotoxic chemotherapy.

For the HRV analysis using as cardiological screening of children before exercise or sport activity, we recommend to evaluate measuring results by every patient this way:

If a short-time variability parameters (HF, MSSD) will be lower then $25^{\text {th }}$ percentile of the reference (Novotný et al. 2008) then next care and examines are needed (echocardiography and others).

Using of the other HRV parameters can fortify predicting and diagnostic capability of HRV analysis. For example there are parameters with the relation to ejection fraction (VLF/LF and VLF/HF rates in lying position and others). The system for HRV analysis facilitates their automatic calculation. Values of these parameters higher than $75^{\text {th }}$ percentile of reference are suspected.

\section{References:}

ASCENSÃO A, MAGALHAES J, SOARES JM. Moderate endurance training prevents doxorubicin-induced in vivo mitichondriopathy and reduces the development of cardiac apoptosis. Am J Heart Circ Physiol, 2008, 289: p. H722-731. ISSN 0363-6135.

BABCOCK DS, PATRICUIN H, LAFORTUNE M et al. Power Doppler sonography : basic principles and clinical applications in children. Pediatric Radiol, 1996, 26, p. 109-115.

BONADUCE D et al. Heart rate variability in patients with hypertrophic cardiomyopathy: association with clinical and echocardiographic features. Am Heart J, 1997, 134, p.165-172.

BOSSI G et al. Echocardiographic evaluation of patients cured of childhood cancer: A single center study of 117 subjects who received antracyclines. Med Ped Oncology, 2001, 36, p. 593-600.

DOVEN O et al. Heart rate variability in hypertrophic obstructive cardiomyopathy: association with functional classification and left ventricular outflow gradients. Int J Cardiol, 2001, 77, p. 281-286. 
Elbl L, Hrstková H, Chaloupka V et al. Stress echocardiography in pediatrics (In Czech: Zátěžová echokardiografie v pediatrii). Čes-slov Pediatr, 2001, 56, p. 427-437.

FOLINO AF, BUJA G, BAUCE B et al. Heart rate variability in arrhytmogenic right ventricular cardiomyopathy correlation with clinical and prognostic features. PACE, 2002, 25, p. 1285-1292.

GANONG WF. Review of Medical Physiology (In Czech: Přehled lékařské fyziologie). Jinočany: H\&H, 1999.

GRIMM W, GLAVERIS CH, HOFMANN J. Noninvasive arrhytmia risk stratification in idiopathic dilated cardiomyopathy. PACE, 1998, 21, p. 2551-2556.

GRIMM W, HERZUM I, MÜLLER HH et al. Value of heart rate variability to predict ventricular arrhytmias in recipients of prophylactic defibrillators with idiopathic dilated cardiomyopathy. PACE, 2003, 26, p. 411-415.

GRIMM W, CHRIST M, SHARKOVA J et al. Arrhytmia risk prediction in idiopathic dilated cardiomyopathy based on heart rate variability and baroreflex sensitivity. PACE, 2005, 28, p. S202-S206.

HAUSER $M$ et al. Diagnosis of anthracycline-induced late cardiomyopathy by exercise-spiroergometry and stress-echocardiography. Eur J Pediatr, 2001, 160, p. 607-610.

HOFMANN J, GRIMM W, MENZ V et al. Heart rate variability and major arrhytmic events in patients with idiopathic dilated cardiomyopathy. PACE, 1996, 19, p. 1841-1844.

HONZÍKOVÁ N. Spectral analysis of circulatory rhythms. Brno: Masaryk University, 1990.

JAVORKA K, ČALKOVSKÁ A, DANKO J et al. Heart rate variability. Mechanism, assessment, clinical using (In Slovak: Variabilita frekvencie srdca. Mechanizmy, hodnotenie, klinické využitie). Martin: Osveta, 2008.

JIMENEZ AA et al. Appraisal of the state of the autonomic nervous system in hypertrophic cardiomyopathy by the analysis of heart rate variability. Rev Esp Cardiol, 1998, 51, p. 286-291.

MÖRNER 2005, WIKLUND U, RASK P et al. Parasympathetic dysfunction in hypertrofic cardiomyopathy assessed by heart rate variability: comparison between short term and 24 -h measurements. Clin Physiol Funct Imaging, 2005, 25, p. 90-99.

NOVOTNÝ J et al. Heart rate variability by healthy children in lying position (In Czech: Variabilita srdeční frekvence u zdravých dětí vleže). Med Sport Boh Slov, 1998, 7, p. 35-40.

NOVOTNÝ J, NOVOTNÁ M. Heart rate variability in children at supine and standing position. Brno: Masaryk University, 2008.

PALACIOS $\mathrm{M}$ et al. Changes of autonomic information flow due to idiopathic dilated cardiomyopathy. Physiol Meas, 2007, 28, 6, p. 677-88.

VAN RAVENSWAAIJ-ARTS CMA et al. Heart rate variability. Ann Int Med, 1993, 118, p. 436-447.

SALINGER J et al. Software of system TF-2 for spectral analysis of R-R interval variation (In Czech: Programové vybavení měřicího systému, typ TF-2, určené pro spektrální analýzu variací R-R intervalů v kardiologii). Lék Tech, 1994, 25, p. 58-62.

SCHNEIDER CM, DENNEHY CA, CARTER SD. Exercise and Cancer Recovery. Champaign: Human Kinetics, 2003: 219 p.

SHIIGI T et al. Relative usefulness of measures of heart rate variability and neuroendocrine activity as indicators of autonomic nervous abnormality in patients with left ventricular dysfunction. Jpn Circ J, 1998,62 , p. 336-340.

ŠTEJFA J et al. Cardiology (In Czech: Kardiologie). Praha: Grada/Avicenum, 1998.

TASK FORCE OF THE EUROPEAN SOCIETY OF CARDIOLOGY AND THE NORTH AMERICAN SOCIETY OF PACING AND ELECTROPHYSIOLOGY. Heart rate variability. Standards of measurements, physiological interpretation, and clinical use. Circulation, 1996, 93, p. 1043-1065.

VALENCIA JF et al. Complexity of the short-term heart rate variability. IEEE Eng Biol Mag, 2009, 28, 6, p. $72-8$.

WALICHIEVICZ $\mathrm{P}$ et al. Use of Fourier row as a method for analyzing the course of circadian heart rate in patients with left ventricular ejection fraction impairment. Pol Arch Med Wewn, 1998, 99, p. 477-486. 